BEATA SZABAŁA

Wydział Pedagogiki i Psychologii

Uniwersytet Marii Curie-Skłodowskiej

Lublin
Forum Pedagogiczne $2016 / 1$

Wpłynęło: 8.12.2015

Zatwierdzono do druku: 3.03.2016

\title{
ROLA SAMOOCENY W KSZTAŁTOWANIU OPTYMIZMU OSÓB SŁABOWIDZĄCYCH
}

\begin{abstract}
Streszczenie: Ukształtowanie się pojęcia własnego Ja ma poważne konsekwencje regulacyjne dla zachowania człowieka, dając m.in. przesłankę do oceniania posiadanych możliwości, ustalania dążeń życiowych i przyjmowania pozytywnej perspektywy przyszłych wydarzeń. Również optymizm oddziałuje na wiele sfer życiowych, m.in. funkcjonowanie społeczne czy zdrowie, zarówno psychiczne, jak i fizyczne. Znaczenie samooceny i optymizmu dla funkcjonowania człowieka oraz powiązań zachodzących pomiędzy tymi zmiennymi jest szczególnie istotne w sytuacji człowieka obciążonego niepełnosprawnością, np. wzrokową. Celem pracy jest określenie roli samooceny w kształtowaniu optymizmu osób słabowidzących i widzących. Badaniami objęto 40 osób słabowidzących i 40 osób widzących w wieku 20-30 lat. Stwierdzono, że samoocena ma znaczenie dla kształtowania się optymizmu badanych $\mathrm{z}$ niepełnosprawnością wzrokową i badanych pełnosprawnych. Ustalony charakter korelacji jest zbieżny z oczekiwanym, chociaż konfiguracja powiązań w obu grupach jest nieco odmienna. Wysunięte założenie hipotetyczne zostało potwierdzone.
\end{abstract}

Słowa kluczowe: samoocena, optymizm, osoby słabowidzące

\section{Wprowadzenie}

Koncepcja siebie jest uporządkowanym schematem, zawierającym epizodyczną i semantyczną pamięć na temat Ja, kontrolującym przetwarzanie dotyczących go informacji. Schemat Ja składa się z dwóch komponentów: samowiedzy i samooceny. Samowiedza odnosi się do przekonań o własnych atrybutach, natomiast samoocena jest pochodną postawy autorefleksyjnej, wyrażającą to, jak ktoś się czuje, kiedy ocenia samego siebie i posiadane atrybuty (Oleś 2005). Zbliżone stanowisko zajmuje Bogdan Wojciszke (2008), który określa samoocenę jako afektywną reakcję człowieka na samego siebie, podobną do innych reakcji afektywnych i mogącą mieć postać zarówno gorącej intensywnej emocji, jak też zimnego zintelektualizowanego sądu. Samoocena jest bardzo często wynikiem szybko zachodzących procesów, przebiegających nieświadomie i automatycznie. Wobec tego trudno jest dokonać 
zwyczajowego rozdzielenia reakcji emocjonalnej i osądu poznawczego. Niektórzy badacze wręcz utożsamiają samoocenę i przeżywane emocje, a nawet uważają, że u podłoża obniżania się samooceny i powstawania negatywnych emocji leżą te same mechanizmy (Huflejt-Łukasik 2010).

Tadeusz Tomaszewski (1995) podkreśla, że zdanie o samym sobie zależy od trzech czynników. Są nimi: doświadczenia jednostki, opinie ludzi i środowiska, w którym żyje, i sytuacja społeczna grupy, do której należy. W związku z tym, że samoocena kształtuje się na podstawie danych pochodzących z opinii otoczenia i doświadczenia człowieka, mogą wystąpić rozbieżności w postrzeganiu siebie. Dzieje się tak, gdy dane te są składowymi doświadczeń z przeszłości i jednocześnie czynnikami upragnionymi. W specyficznej sytuacji znajdują się osoby z niepełnosprawnością, które często doświadczają różnych trudności będących komplikacją posiadanej niepełnosprawności. Trudności te mają charakter psychologiczno-społeczny i są zależne od rodzaju niepełnosprawności, dotyczą np. poznawania i uczenia się, komunikowania się, przemieszczania. W subiektywnym odczuciu osoby z niepełnosprawnością mogą one zajmować znaczące miejsce, zwłaszcza wówczas, gdy nie potrafi ona sobie z nimi poradzić, a ich przyczyna zdominowała nawet posiadane zalety (Sękowski 2001). Sprzyja to powstawaniu zakłóceń w określeniu faktycznego poziomu samooceny.

Ogólnie rzecz biorąc, samoocena, a w szczególności jej rodzaj, w istotny sposób wiąże się z psychospołecznym funkcjonowaniem człowieka, prowadząc do specyficznych objawów w sferze emocjonalnej, osobowościowej i społecznej. Dla optymalnego funkcjonowania człowieka ważne jest, aby była adekwatna. Samoocena taka stanowi ochronę przed stresem i pomaga człowiekowi w obliczu traumy czy nieszczęścia, bo zapas pozytywnych uczuć czyni go mniej podatnym na zranienia i depresję. Osoba z adekwatnym poczuciem własnej wartości zazwyczaj jest ekstrawertykiem przejawiającym inicjatywę, posiadającym zdolności komunikacyjne, a w rezultacie wywierającym dobre wrażenie (Fila-Jankowska 2009). Cechuje ją niezależność, elastyczność, racjonalizm, realizm, zdolność radzenia sobie ze zmianą, łatwość przyznawania się do błędów i ich korygowania, życzliwość, gotowość do współpracy oraz intuicja i twórczość (Lindenfield 1995). Adekwatna samoocena jest warunkiem niezbędnym do utrzymania zdrowia psychicznego i dobrego samopoczucia. Stanowi też jedną z podstawowych potrzeb człowieka. Wiąże się $z$ poczuciem bycia kimś kompetentnym, lubianym przez inne osoby i moralnym. Pozwala na wytyczanie sobie ambitnych, ale możliwych do zrealizowania celów (Kofta, Doliński 200o). Janusz Kirenko (2002) podkreśla, że człowiek z adekwatną samooceną najczęściej jest po prostu człowiekiem szczęśliwym.

Rozważania teoretyczne dotyczące samooceny pokazują, że ukształtowanie się pojęcia własnego Ja pełni funkcję regulacyjną w życiu człowieka, dając przesłankę do oceniania posiadanych możliwości, określania samopoczucia, stawiania sobie wymagań, planowania przyszłości i ustalania dążeń życiowych. Samoocena warunkuje ponadto samoakceptację, samoodtrącenie, rodzaj podejmowanej aktywności, 
odporność emocjonalną, odporność na zmęczenie oraz subiektywną ocenę szans na osiągnięcie sukcesu (Kofta, Doliński 200o). W literaturze przedmiotu zwraca się także uwagę na powiązania pomiędzy samooceną a optymizmem (El-Anzi 2005; Łaguna i in. 2007; Scheier, Carver 1992; Zeigler-Hill, Terry 2007).

Pojęcie optymizmu wiąże się głównie z nazwiskami Michaela F. Scheiera i Charlesa S. Carvera oraz Martina E. Seligmana. Optymizm w ujęciu Scheiera i Carvera (1992) rozumiany jest jako cecha dyspozycyjna, określająca ogólne, trwałe i niezależne od sytuacji oczekiwanie raczej pozytywnych niż negatywnych wydarzeń w przyszłości. Odnosi się to nie tylko do rezultatów własnego działania, ale również do wyników zupełnie niezależnych od zachowań, przypisywanych m.in. szczęściu czy zbiegowi okoliczności (Carver, Scheier 2002). Martin E. Seligman (2002) definiuje optymizm w nawiązaniu do stylu wyjaśniania, czyli nawykowego sposobu tłumaczenia sobie przez ludzi przydarzających się wydarzeń pozytywnych i negatywnych. Optymizm rozwija się pod wpływem czynników biologicznych, w tym dziedziczenia i temperamentu (Seligman 2005; Stach 2006), oraz jako efekt oddziaływania czynników środowiskowych, tj. wpływu rodziców, nauczycieli, doświadczeń z wczesnego okresu życia (Seligman 2005).

W literaturze przedmiotu można odnaleźć wiele propozycji podziału optymizmu. Kenneth A. Wallston (1994) wyodrębnił optymizm ostrożny i zuchwały. Ostrożny optymista uwzględnia otaczającą rzeczywistość, robi wszystko, by osiągnąć zamierzony cel, nawet jeśli okoliczności temu nie sprzyjają. Zuchwały optymista żyje w świecie pełnym złudzeń, wierząc, że wszystkie jego zamierzenia mogą zakończyć się sukcesem, nawet jeśli sam nie podejmie właściwych działań. Ralf Schwarzer (1994) proponuje podział na optymizm defensywny i funkcjonalny. Ten pierwszy wiąże się z nierealistycznie wysoką oceną subiektywnych szans uniknięcia przykrych zdarzeń. Ma on charakter emocjonalny. Drugi natomiast oznacza wysokie poczucie własnej skuteczności. Pełniąc funkcję przystosowawczą, motywuje m.in. do aktywnego radzenia sobie ze stresem $\mathrm{w}$ kontekście poczucia własnej skuteczności. Tak rozumiany optymista bierze pod uwagę ewentualność porażki, którą interpretuje w możliwy dla siebie sposób. Janusz Czapiński (2012) dokonał podziału optymizmu na trzy kategorie, które wywodzą się z trzech rodzajów ufności. Pierwszy z nich określa wiarę w siebie i swoje umiejętności, drugi to ufność ukierunkowana na innych ludzi, trzeci zaś związany jest $\mathrm{z}$ wiarą w pomoc sił nadprzyrodzonych. Natomiast Ryszard Stach (2006) wyróżnił optymizm esencjonalny i sprawczy. Esencjonalny odnosi się do uogólnionej pozytywnej oceny świata, a sprawczy polega na oczekiwaniu i przewidywaniu konkretnych pozytywnych zdarzeń.

Niezależnie od przyjmowanej koncepcji optymizmu wyniki badań empirycznych wskazują, że w znaczący sposób wiąże się on z funkcjonowaniem człowieka. Wpływa na wiele sfer życiowych, m.in. na funkcjonowanie społeczne czy zdrowie, zarówno psychiczne, jak i fizyczne. Optymistyczny sposób bycia jest atrakcyjny dla ewentualnych partnerów relacji społecznych i przyczynia się do kształtowania 
rozległych, wspierających sieci społecznych. Optymiści są bardziej lubiani niż pesymiści, dlatego też mają mniej negatywnych interakcji społecznych. Utrzymują swoje przyjaźnie przez dłuższy czas i doświadczają większego wsparcia społecznego (Karademas 2006; Segerstrom 2007; Shelby i in. 2008).

Optymistyczne myślenie podnosi motywację, zwiększa wytrwałość i determinację w osiąganiu celów. Jest związane z ustalaniem wysokich standardów i aspiracji oraz sukcesami w rozwiązywaniu problemów (Oettingen, Mayer 2002), gdyż ułatwia podejmowanie decyzji w sytuacjach trudnych. Z badań wynika, że optymiści różnią się od pesymistów w zakresie preferowanych strategii radzenia sobie ze stresem. Pierwsi mają skłonność do częstego stosowania aktywnych strategii zaradczych, a jeśli one zawodzą, stosują adaptacyjne sposoby skoncentrowane na emocjach. U drugich natomiast dominują strategie ucieczkowe, tendencja do zaprzeczania, odwracania uwagi i zaprzestawania działań (Ben-Zur i in. 200o; Ben-Zur, Debi 2005; Poprawa 2001; Scheier i in. 1994). Ponadto optymiści są skłonni do przeformułowywania znaczenia kryzysowej sytuacji, której nie można zmienić. Dzięki temu optymizm pełni funkcję prozdrowotną, gdyż stres jest istotnym czynnikiem negatywnie wpływającym na dobrostan psychofizyczny (Poprawa 2001).

Optymiści, w porównaniu z pesymistami, doświadczają znacznie więcej pozytywnych uczuć (Juczyński 2001), chętniej przeżywają nowe doświadczenia i łatwiej się do nich przystosowują. Cechuje ich pewna plastyczność poznawcza, są bardziej twórczy i otwarci na zmiany (Isen 2012). Wyniki badań potwierdzają także związek optymizmu z satysfakcją z życia (Juczyński 2001) i nadzieją (Trzebiński, Zięba 2003). Oczekiwanie pozytywnych wydarzeń wpływa korzystnie na ocenę życia, jego jakość oraz zadowolenie z siebie (Czapiński 2012; Schwarzer 1994). Nadzieja natomiast skutkuje tym, że optymizm staje się bardziej stabilny i mniej zależny od aktualnych doświadczeń osobistych (Trzebiński, Zięba 2003).

Optymizm pozytywnie koreluje z dobrym stanem zdrowia. Optymistyczne nastawienie do życia współwystępuje z uzyskiwaniem lepszych wyników w obszarach bezpośrednio związanych ze zdrowiem, takich jak: ogólna ocena zdrowia, witalność, aktywność i sprawność fizyczna, dolegliwości bólowe, funkcjonowanie społeczne, stan zdrowia psychicznego, nastawienie emocjonalne (Stach 2006). Badania wskazują, że optymiści lepiej dbają o swoje zdrowie i częściej podejmują zachowania prozdrowotne (Baker 2007; Łatka i in. 2013). Warto podkreślić, że optymizm nie tylko sprzyja zdrowiu, ale też wydłuża życie człowieka (Seligman 2002) - według badań aż o 7,5 roku (Czapiński 2005).

Zważywszy zatem na znaczenie samooceny i optymizmu dla funkcjonowania człowieka, należy zwrócić uwagę na powiązania zachodzące pomiędzy tymi zmiennymi, co nabiera szczególnego znaczenia w sytuacji człowieka obciążonego niepełnosprawnością, np. wzrokową. Jest to tym bardziej zasadne, że trudno odnaleźć podobne analizy w literaturze przedmiotu. 


\section{Cel pracy}

Celem podjętych badań jest określenie roli samooceny w kształtowaniu optymizmu osób słabowidzących. Wprowadzenie do badań grupy porównawczej - osób widzących - stworzyło możliwość wnioskowania odnośnie do różnic i podobieństw między obiema grupami w zakresie samooceny, optymizmu, a zwłaszcza powiązań między tymi zmiennymi. W związku z tym problemy badawcze sformułowane w kontekście założonych celów przyjęły następującą postać:

1. Jaki jest poziom optymizmu osób słabowidzących w stosunku do tego, jaki cechuje osoby widzące?

2. Jaką samoocenę mają osoby słabowidzące? Czy różni się ona od tej, która jest udziałem osób widzących?

3. Czy istnieją, a jeśli tak, to jaki mają charakter, zależności pomiędzy samooceną a optymizmem osób słabowidzących i na ile zachodzące powiązania są zbieżne z tymi, jakie obserwuje się u osób widzących?

Jak twierdzi Mieczysław Łobocki (2007), formułowanie hipotez roboczych nie jest konieczne, gdy przyjęty problem badawczy dotyczy wyłącznie opisu pewnych zjawisk lub faktów. Niejednoznaczne doniesienia empiryczne na temat ewentualnych różnic pomiędzy osobami słabowidzącymi i widzącymi w zakresie samooceny (López--Justicia, Nieto-Córdoba 2006; Martinez, Sewell 1996) oraz niedostatek takowych eksploracji w odniesieniu do optymizmu (Ben-Zur, Debi 2005; Moore, Miller 2003) nie pozwalają na przyjęcie jednoznacznych rozwiązań hipotetycznych w stosunku do problemów zawartych w pierwszym i drugim pytaniu badawczym. $\mathrm{Na}$ podstawie zgromadzonych analiz teoretycznych uzasadnione jest natomiast sformułowanie hipotezy odnoszącej się do trzeciego problemu badawczego. Zakłada się, że istnieje zależność pomięd zy samooceną osób z niepełnosprawnością wzrokową i osób pełnosprawnych a ich optymizmem. Uzasadniając takie założenie, można odwołać się do podawanej w literaturze przedmiotu tezy, wysuniętej przez Michaela F. Scheiera i Charlesa S. Carvera (1992), że optymizm współwystępuje z pozytywną samooceną, samoakceptacją i poczuciem własnej wartości. Na istniejące pomiędzy tymi zmiennymi pozytywne powiązania wskazuje także wiele innych prac empirycznych (El-Anzi 2005; Lemola 2013; Łaguna i in. 2007; ZeiglerHill, Terry 2007).

\section{Materiał i metoda}

Badaniami objęto 40 osób słabowidzących (grupa podstawowa) i 40 osób widzących (grupa porównawcza) w wieku 20-30 lat ${ }^{1}$. W grupie podstawowej znalazło się 27 kobiet (65,50\%) i 13 mężczyzn (32,50\%). Dominowali mieszkańcy miast (26 osób, tj. 65\%). Najwięcej respondentów miało przyznany znaczny (17 osób, tj. 42,50\%)

\footnotetext{
1 Prezentowane wyniki są częścią szerzej zakrojonych badań.
} 
lub umiarkowany (16 osób, tj. 40\%) stopnień niepełnosprawności wzrokowej, najmniej - lekki (7 osób, tj. 17,50\%). Grupa porównawcza została dobrana intencjonalnie według takich kryteriów, jak wiek, płeć, miejsce zamieszkania. Wobec tego jej socjodemograficzna charakterystyka jest zbieżna $\mathrm{z}$ danymi grupy podstawowej.

Materiał empiryczny zebrano za pomocą następujących narzędzi badawczych: Test Orientacji Życiowej (LOT-R) Michaela F. Scheiera i Charlesa S. Carvera w adaptacji Ryszarda Poprawy i Zygfryda Juczyńskiego, Skala Samooceny (TSCS) Williama H. Fittsa, kwestionariusz ankiety własnej konstrukcji.

Test Orientacji Życiowej pozwala ustalić poziom optymizmu dyspozycyjnego i opiera się na koncepcji jednowymiarowości optymizmu. Narzędzie to składa się Z 10 twierdzeń, spośród których 6 ma wartość diagnostyczną, a 4 pozostałe służą jako pozycje buforowe. Badany, dysponując 5-stopniową skalą, określa, na ile dane twierdzenie odnosi się do niego (Juczyński 2001).

Skala Samooceny cechuje się wielowymiarowością w zakresie opisu koncepcji siebie i samooceny. Składa się ze 100 opisowych twierdzeń, odnoszących się do cech obrazu siebie, ocenianych 5-punktowo. Pozwala dokonać subiektywnej oceny badanej osoby na trzech poziomach (Tożsamość, Akceptacja, Zachowanie) oraz w pięciu kolumnach (Ja fizyczne, Ja moralno-etyczne, Ja osobiste, Ja rodzinne, Ja społeczne). Interpretacji podlegają także skale: Samokrytycyzm, Wskaźnik prawda/ fałsz, Punktacja konfliktów netto, Punktacja konfliktów razem, Ogólna punktacja pozytywna, Ogólna zmienność, Zmienność w kolumnach, Zmienność w rzędach, Dystrybucja (Kirenko, Sarzyńska 2010).

Kwestionariusz ankiety posłużył do zebrania danych socjodemograficznych o respondentach.

\section{Wyniki}

\section{Optymizm badanych osób}

Analiza ujawniła, że osoby z niepełnosprawnością wzrokową nie różnią się na poziomie ufności statystycznej od osób pełnosprawnych pod względem optymizmu, z tym że średnia badanych słabowidzących jest niższa od analogicznej średniej badanych widzących. Oznacza to, że osoby z niepełnosprawnością wzrokową, $\mathrm{w}$ porównaniu $\mathrm{z}$ osobami pełnosprawnymi, posiadają mniej optymistyczną perspektywę przyszłych wydarzeń życiowych.

Tabela 1. Optymizm osób z grupy podstawowej (A) i osób z grupy porównawczej (B) średnie arytmetyczne, odchylenia standardowe, istotność różnic

\begin{tabular}{cccccc}
\hline \multicolumn{2}{c}{ Grupa A } & \multicolumn{2}{c}{ Grupa B } & \multicolumn{2}{c}{ Porównanie średnich } \\
\hline $\mathrm{x}$ & $\mathrm{s}$ & $\mathrm{x}$ & $\mathrm{s}$ & $\mathrm{t}$ & $\mathrm{p}$ \\
\hline 15,15 & 4,41 & 16,05 & 4,00 & $-0,96$ & 0,342 \\
\hline
\end{tabular}

$\mathrm{x}$ - średnia arytmetyczna, $\mathrm{s}$ - odchylenie standardowe, $\mathrm{t}$ - wartość testu t-Studenta, $\mathrm{p}$ - poziom istotności 
Tabela 2. Optymizm osób z grupy podstawowej (A) i osób z grupy porównawczej (B) wyniki przeliczone ${ }^{2}$

\begin{tabular}{llllll}
\hline & Grupa A & \multicolumn{3}{c}{ Grupa B } \\
\hline $\begin{array}{l}\text { Wyniki } \\
\text { niskie }\end{array}$ & Wyniki & Wyniki & Wyniki & Wyniki & Wyniki \\
przeciętne & wysokie & niskie & przeciętne & wysokie \\
\hline $5(12,50 \%)$ & $27(67,50 \%)$ & $8(20,00 \%)$ & $4(10,00 \%)$ & $25(62,50 \%)$ & $11(27,50 \%)$ \\
\hline
\end{tabular}

$\mathrm{Na}$ istniejące pomiędzy grupami rozbieżności, wprawdzie niewielkie, wskazuje także rozkład wartości przeliczonych. Wynika z niego, że odsetek badanych z grupy podstawowej z wynikami przeciętnymi jest wyższy niż w grupie porównawczej, zbliżony w obrębie wartości niskich, ale mniejszy w wysokich.

\section{Samoocena badanych osób}

Z danych zamieszczonych w tabeli 3. wynika, że występują pewne różnice w zakresie samooceny osób niepełnosprawnych wzrokowo i pełnosprawnych. W większości skal TSCS korzystniejsze wyniki są udziałem badanych widzących. Analiza ujawniła, że osoby z grupy A, w porównaniu z osobami z grupy B, wykazują znacznie mniej nasiloną tendencję do przypisywania sobie cech dodatnich w związku z kierowaniem się w życiu wartościami moralnymi, mają istotnie niższe poczucie własnej wartości, mniej pozytywnie oceniają swoją osobowość w odrębności od swojego ciała i stosunku do innych. Charakteryzuje je również znacznie mniej pozytywny obraz siebie jako członków rodziny i istotnie słabsze poczucie adekwatności własnej wartości w interakcjach społecznych.

Tabela 3. Samoocena osób z grupy podstawowej (A) i osób z grupy porównawczej (B) średnie arytmetyczne, odchylenia standardowe, istotność różnic

\begin{tabular}{lcccccc}
\hline \multirow{2}{*}{ Skale TSCS } & \multicolumn{2}{c}{ Grupa A } & \multicolumn{2}{c}{ Grupa B } & \multicolumn{2}{r}{ Porównanie średnich } \\
\cline { 2 - 7 } & $\mathrm{x}$ & $\mathrm{s}$ & $\mathrm{x}$ & $\mathrm{s}$ & $\mathrm{t}$ & $\mathrm{p}$ \\
\hline Samokrytycyzm & 34,78 & 7,12 & 36,03 & 5,36 & $-0,89$ & 0,378 \\
\hline Wskaźnik prawda/fałsz & 1,26 & 0,40 & 1,32 & 0,36 & $-0,74$ & 0,460 \\
\hline $\begin{array}{l}\text { Punktacja konfliktów } \\
\text { netto }\end{array}$ & 67,28 & 34,40 & 71,35 & 50,16 & $-0,42$ & 0,673 \\
\hline
\end{tabular}

${ }^{2}$ Wyniki przeliczone wyznaczono z wykorzystaniem metody uwzględniającej średnią arytmetyczną i odchylenie standardowe. 


\begin{tabular}{lcccccc}
\hline \multirow{2}{*}{ Skale TSCS } & \multicolumn{2}{c}{ Grupa A } & \multicolumn{2}{c}{ Grupa B } & \multicolumn{2}{c}{ Porównanie średnich } \\
\cline { 2 - 7 } & $\mathrm{x}$ & $\mathrm{s}$ & $\mathrm{x}$ & $\mathrm{s}$ & $\mathrm{t}$ & $\mathrm{p}$ \\
\hline $\begin{array}{l}\text { Punktacja konfliktów } \\
\text { razem }\end{array}$ & 74,25 & 29,37 & 82,83 & 29,86 & $-1,29$ & 0,199 \\
\hline $\begin{array}{l}\text { Ogólna punktacja } \\
\text { pozytywna }\end{array}$ & 271,58 & 16,06 & 280,76 & 36,98 & $-1,44$ & 0,153 \\
\hline Tożsamość & 84,33 & 9,26 & 87,08 & 8,61 & $-1,38$ & 0,173 \\
\hline Akceptacja & 91,23 & 7,43 & 93,10 & 7,41 & $-1,13$ & 0,262 \\
\hline Zachowanie & 96,15 & 8,37 & 97,63 & 7,42 & $-0,83$ & 0,407 \\
\hline Ja fizyczne & 53,25 & 11,71 & 55,90 & 4,65 & $-1,33$ & 0,187 \\
\hline Ja moralno-etyczne & 51,05 & 11,51 & 55,25 & 4,41 & $-2,16$ & 0,034 \\
\hline Ja osobiste & 48,73 & 10,50 & 53,28 & 5,84 & $-2,40$ & 0,019 \\
\hline Ja rodzinne & 51,45 & 11,64 & 55,48 & 4,84 & $-2,02$ & 0,047 \\
\hline Ja społeczne & 51,20 & 11,95 & 55,85 & 4,37 & $-2,31$ & 0,023 \\
\hline Ogólna zmienność & 40,50 & 14,68 & 37,68 & 9,64 & 1,02 & 0,312 \\
\hline $\begin{array}{l}\text { Zmienność } \\
\text { w kolumnach }\end{array}$ & 17,78 & 8,91 & 15,98 & 4,03 & 1,16 & 0,248 \\
\hline Zmienność w rzędach & 23,63 & 9,08 & 21,70 & 7,05 & 1,06 & 0,293 \\
\hline Dystrybucja & 114,80 & 36,41 & 112,10 & 20,76 & 0,41 & 0,684 \\
\hline Objnic & & & & &
\end{tabular}

Objaśnienie skrótów jak w tabeli 1.

Z danych pozostałych skal, w których nie pojawiły się znaczące różnice pomiędzy grupami, wynika, że badani słabowidzący, w porównaniu z badanymi widzącymi, w większym stopniu są skłonni do ukazywania siebie w lepszym świetle, definiują własne Ja w sposób mniej harmonijny i posiadają mniejszy potencjał do charakteryzowania siebie poprzez koncentrację na sobie. Przejawiają mniejszą tendencję do konfliktu zaprzeczenia, wskazując tym samym, że nie zaprzeczają nadmiernie swoim cechom negatywnym w porównaniu $\mathrm{z}$ tym, jak potwierdzają swoje cechy pozytywne, rzadziej występują u nich konflikty w zakresie odbioru własnego Ja i niestabilność emocjonalna. Na podstawie uzyskanych danych można wnioskować, że badani z niepełnosprawnością wzrokową uznają się za osoby mniej wartościowe, mniej akceptujące siebie i ufające sobie. Cechuje je niższy poziom poczucia tożsamości, słabsza identyfikacja z własnym Ja, stawianie sobie mniejszych wymagań, jak również niższy poziom samoakceptacji i samozadowolenia. Ponadto badani słabowidzący mniej pozytywnie oceniają swoje zachowanie, mają skłonność do przypisywania sobie niższych ocen, zwracają mniejszą uwagę na swoje ciało, zdrowie oraz wygląd fizyczny i odznaczają się większą tendencją do braku jedności pomiędzy poszczególnymi sferami własnego Ja. Z badań wynika także, że osoby 
z grupy podstawowej wykazują większą zmienność percepcyjną poszczególnych sfer obrazu siebie, niższy poziom integracji sfer własnego Ja i silniejszą skłonność do izolowania pewnych sfer własnego Ja od pozostałych sfer. Pomimo to badani z niepełnosprawnością wzrokową ujawniają większe zdecydowanie i pewność siebie w tym, co robią, oraz mniejszą defensywność w zakresie percepcji i prezentowania obrazu własnej osoby.

Zauważone prawidłowości potwierdza analiza wartości przeliczonych. Z zestawienia danych wynika, że odsetek osób słabowidzących otrzymujących w skali Samokrytycyzm wyniki niskie jest większy od analogicznego odsetka osób widzących, ale już mniejszy w obrębie wartości przeciętnych i zbliżony w wysokich. Identyczną sytuację obserwuje się w skalach: Wskaźnik prawda/fałsz, Punktacja konfliktów netto, Punktacja konfliktów razem. Kolejne zróżnicowanie wyników pomiędzy grupami zauważa się w skalach Ogólna punktacja pozytywna i Ja rodzinne, gdzie odsetek osób z grupy A z wynikami niskimi i przeciętnymi przewyższa ten opisujący grupę B, jakkolwiek przy mniejszych odsetkach w kategorii wartości wysokich. W skali Tożsamość odsetek badanych z niepełnosprawnością wzrokową z wynikami niskimi i wysokimi jest większy od odsetka pełnosprawnych, ale już mniejszy w obrębie wyników przeciętnych. Taki sam układ wartości dotyczy skali Akceptacja. Inną strukturę wyników przeliczonych obserwuje się w następnych skalach TSCS, tzn. Zachowanie, Ja moralno-etyczne, Ja osobiste, w których zbliżonym lub równym w obu grupach wartościom niskim towarzyszy zróżnicowanie w zakresie wyników przeciętnych i wysokich, z tym że odsetek tych pierwszych jest większy w grupie podstawowej, a drugich - w grupie porównawczej.

Tabela 4. Samoocena osób z grupy podstawowej (A) i osób z grupy porównawczej (B) wyniki przeliczone ${ }^{3}$

\begin{tabular}{lcccccc}
\hline \multirow{2}{*}{ Skale TSCS } & \multicolumn{3}{c}{ Grupa A } & \multicolumn{3}{c}{ Grupa B } \\
\cline { 2 - 7 } & $\begin{array}{c}\text { Wyniki } \\
\text { niskie }\end{array}$ & $\begin{array}{c}\text { Wyniki } \\
\text { przeciętne }\end{array}$ & $\begin{array}{c}\text { Wyniki } \\
\text { wysokie }\end{array}$ & $\begin{array}{c}\text { Wyniki } \\
\text { niskie }\end{array}$ & $\begin{array}{c}\text { Wyniki } \\
\text { przeciętne }\end{array}$ & $\begin{array}{c}\text { Wyniki } \\
\text { wysokie }\end{array}$ \\
\hline Samokrytycyzm & $8(20,00)$ & $25(62,50)$ & $7(17,50)$ & $5(12,50)$ & $29(72,50)$ & $6(15,00)$ \\
\hline $\begin{array}{l}\text { Wskaźnik } \\
\text { prawda/fałsz }\end{array}$ & $6(15,00)$ & $25(62,50)$ & $9(22,50)$ & $2(5,00)$ & $30(75,00)$ & $8(20,00)$ \\
\hline $\begin{array}{l}\text { Punktacja kon- } \\
\text { fliktów netto }\end{array}$ & $6(15,00)$ & $29(72,50)$ & $5(12,50)$ & $4(10,00)$ & $32(80,00)$ & $4(10,00)$ \\
\hline $\begin{array}{l}\text { Punktacja kon- } \\
\text { lliktów razem }\end{array}$ & $7(17,50)$ & $27(67,50)$ & $6(15,00)$ & $2(5,00)$ & $31(77,50)$ & $7(17,50)$ \\
\hline
\end{tabular}

${ }^{3}$ Wyniki przeliczone wyznaczono z wykorzystaniem metody uwzględniającej średnią arytmetyczną i odchylenie standardowe. 


\begin{tabular}{lcccccc}
\hline $\begin{array}{l}\text { Ogólna punkta- } \\
\text { cja pozytywna }\end{array}$ & $7(17,50)$ & $27(67,50)$ & $6(15,00)$ & $1(2,50)$ & - & $39(97,50)$ \\
\hline Tożsamość & $6(15,00)$ & $27(67,50)$ & $7(17,50)$ & $3(7,50)$ & $33(82,50)$ & $4(10,00)$ \\
\hline Akceptacja & $7(17,50)$ & $26(65,00)$ & $7(17,50)$ & $5(12,50)$ & $30(75,00)$ & $5(12,50)$ \\
\hline Zachowanie & $5(12,50)$ & $31(77,50)$ & $4(10,00)$ & $6(15,00)$ & $17(42,50)$ & $17(42,50)$ \\
\hline Ja fizyczne & $4(10,00)$ & $33(82,50)$ & $3(7,50)$ & $9(22,50)$ & $24(60,00)$ & $7(17,50)$ \\
\hline Ja & $7(17,50)$ & $32(80,00)$ & $1(2,50)$ & $6(15,00)$ & $26(65,00)$ & $8(20,00)$ \\
moralno-etyczne & $4(10,00)$ & $35(87,50)$ & $1(2,50)$ & $4(10,00)$ & $30(75,00)$ & $6(15,00)$ \\
\hline Ja osobiste & $10(25,00)$ & $29(72,50)$ & $1(2,50)$ & $8(20,00)$ & $24(60,00)$ & $8(20,00)$ \\
\hline Ja rodzinne & $4(10,00)$ & $34(85,00)$ & $2(5,00)$ & $7(17,50)$ & $26(65,00)$ & $7(17,50)$ \\
\hline Ja społeczne & $4(10,00)$ & $28(70,00)$ & $8(20,00)$ & $8(20,00)$ & $25(62,50)$ & $7(17,50)$ \\
\hline $\begin{array}{l}\text { Ogólna } \\
\text { zmienność }\end{array}$ & $1(2,50)$ & $33(82,50)$ & $6(15,00)$ & $8(20,00)$ & $28(70,00)$ & $4(10,00)$ \\
\hline $\begin{array}{l}\text { Zmienność } \\
\text { w kolumnach }\end{array}$ & $6(15,00)$ & $27(67,50)$ & $6(15,00)$ & $8(20,00)$ & $27(67,50)$ & $5(12,50)$ \\
\hline $\begin{array}{l}\text { Zmienność } \\
\text { w rzędach }\end{array}$ & $7(17,50)$ & $27(67,50)$ & $6(15,00)$ & $9(22,50)$ & $25(62,50)$ & $6(15,00)$ \\
\hline \begin{tabular}{l} 
Dystrybucja \\
\hline
\end{tabular} & & & & & &
\end{tabular}

Układ wyników przeliczonych uzyskanych w skalach Ogólna zmienność i Dystrybucja odbiega od zaprezentowanych wcześniej i różnicuje badane grupy, gdyż odsetek osób słabowidzących osiągających wyniki niskie jest mniejszy od odsetka osób widzących, ale większy w zakresie wartości przeciętnych i zbliżony lub równy w wysokich. Podobną strukturę, oprócz wyników wysokich, gdzie zaznaczyła się pewna rozbieżność, zauważa się w przypadku skal: Ja fizyczne, Ja społeczne i Zmienność w kolumnach. Jeszcze inny rozkład wartości przeliczonych obserwuje się w skali Zmienność w rzędach, gdzie odsetek badanych z niepełnosprawnością wzrokową uzyskujących wyniki niskie jest mniejszy od analogicznego odsetka badanych pełnosprawnych, przy równych odsetkach w obrębie wartości przeciętnych i zbliżonych w wartościach wysokich.

\section{Samoocena a optymizm badanych osób}

Nadrzędnym celem niniejszego artykułu jest określenie powiązań zachodzących pomiędzy samooceną a optymizmem badanych osób z obu grup, co ustalano za pomocą procedury korelacyjnej. Jej wyniki są zawarte w tabeli 5. 
Tabela 5. Samoocena a optymizm osób z grupy podstawowej (A) i osób z grupy porównawczej (B) - analiza korelacyjna

\begin{tabular}{lcc}
\hline \multirow{2}{*}{ Skale TSCS } & \multicolumn{2}{c}{ Optymizm } \\
\cline { 2 - 3 } & Grupa A & Grupa B \\
\hline Samokrytycyzm & $-0,01$ & $-0,34^{*}$ \\
\hline Wskaźnik prawda/fałsz & $0,31 \sim$ & $-0,28$ \\
\hline Punktacja konfliktów netto & 0,24 & $-0,60^{* * *}$ \\
\hline Punktacja konfliktów razem & 0,26 & $-0,51^{* * *}$ \\
\hline Ogólna punktacja pozytywna & $0,36^{*}$ & $0,41^{*}$ \\
\hline Tożsamość & $-0,06$ & $0,37^{*}$ \\
\hline Akceptacja & $0,46^{* *}$ & $0,43^{*}$ \\
\hline Zachowanie & $0,36^{*}$ & $-0,05$ \\
\hline Ja fizyczne & 0,14 & $0,30 \sim$ \\
\hline Ja moralno-etyczne & 0,05 & $-0,12$ \\
\hline Ja osobiste & $0,34^{*}$ & 0,23 \\
\hline Ja rodzinne & $0,47^{* *}$ & 0,21 \\
\hline Ja społeczne & 0,21 & $-0,14$ \\
\hline Ogólna zmienność & $-0,11$ & 0,04 \\
\hline Zmienność w kolumnach & $-0,08$ & $-0,09$ \\
\hline Zmienność w rzędach & $-0,04$ & 0,10 \\
\hline Dystrybucja & 0,11 & 0,2 \\
\hline$\sim$ p<o,10; ${ }^{*}<<0,05 ;{ }^{* *}<<0,01 ;{ }^{* * * p<0,001}$ & &
\end{tabular}

$\mathrm{Z}$ analizy korelacyjnej przeprowadzonej w grupie podstawowej wynika, że istnieją zależności pomiędzy samooceną a optymizmem osób słabowidzących; 5 współczynników jest istotnych statystycznie, a 1 ma wartość zbliżoną do istotności. Wszystkie określają współzależności dodatnie.

Analiza powiązań, jakie zauważa się pomiędzy samooceną a optymizmem badanych z niepełnosprawnością wzrokową, wskazuje, że skala Ja rodzinne umiarkowanie koreluje z optymizmem $(0,47)$. Jest to zależność istotna statystycznie. Odwołując się do uzyskanych wartości, można przyjąć, że pozytywny obraz siebie osób słabowidzących jako członków rodziny wiąże się z ich optymistyczną perspektywą przyszłych wydarzeń życiowych.

Korelację podobną do wyżej opisanej zauważa się w przypadku skali Akceptacja, która umiarkowanie istotnie powiązana jest $z$ optymizmem $(0,46)$. Dane te pozwalają wnioskować, że osoby z grupy podstawowej ujawniające wyższy poziom 
samoakceptacji i samozadowolenia są równocześnie optymistycznie nastawione do życia.

Wyniki uzyskane w skali Ogólna punktacja pozytywna nisko korelują z optymizmem (o,36), zależność ta osiąga poziom ufności statystycznej. Zawartość treściowa analizowanej skali samooceny sugeruje, że niepełnosprawni wzrokowo, postrzegający siebie jako osoby wartościowe, lubiące siebie, ufające sobie, generalnie oczekują pozytywnych wydarzeń.

Przeprowadzona analiza korelacyjna wskazuje także na niskie, ale istotne powiązania pomiędzy skalą Zachowanie a optymizmem $(0,36)$. W odniesieniu do opisanych wartości należy stwierdzić, że pozytywna ocena swojego zachowania dokonywana przez osoby słabowidzące współwystępuje z optymistyczną perspektywą przyszłych wydarzeń życiowych.

Podobne współzależności zauważa się w przypadku skali Ja osobiste i optymizmu $(0,34)$. Uzyskany współczynnik informuje, że badani z grupy podstawowej, pozytywniej oceniający swoją osobowość w odrębności od swojego ciała i stosunku do innych, przyjmują również optymistyczne nastawienie do życia.

Wyniki analizy korelacyjnej ujawniają też jeden niski związek zależnościowy, który ma wartość zbliżoną do istotności. Dotyczy on powiązań, jakie zaznaczyły się pomiędzy skalą Wskaźnik prawda/fałsz a optymizmem $(0,31)$. Biorąc pod uwagę dane liczbowe, można przyjąć, że definiowanie własnego Ja w sposób znacznie bardziej harmonijny, a więc z jednej strony afirmowanie tego, co wchodzi w skład Ja osób z niepełnosprawnością wzrokową, a z drugiej odrzucanie tego, czego ono nie obejmuje, wiąże się z oczekiwaniem generalnie pozytywnych wydarzeń.

Dokonując podobnych analiz w grupie porównawczej (tabela 5.), zauważa się, że samoocena osób pełnosprawnych ma znaczenie dla kształtowania się ich optymizmu dyspozycyjnego. Zaobserwowano 6 współczynników o charakterze istotnym statystycznie, a 1 osiągnął wartość zbliżoną do poziomu ufności. Część spośród nich opisuje współzależności dodatnie, a część ujemne.

Analiza związków zależnościowych zachodzących pomiędzy samooceną a optymizmem badanych widzących ujawnia, że skala Punktacja konfliktów netto koreluje umiarkowanie z optymizmem $(-0,60)$. Jest to zależność ujemna istotna statystycznie. Odwołując się do uzyskanych wartości, można przypuszczać, że osoby pełnosprawne, przejawiające mniejszą skłonność do konfliktu zaprzeczenia, wskazujące tym samym, że nie zaprzeczają nadmiernie swoim cechom negatywnym w porównaniu z tym, jak potwierdzają swoje cechy pozytywne, charakteryzują się optymistyczną perspektywą przyszłych wydarzeń życiowych.

Wyniki analizy korelacyjnej wskazują na umiarkowanie istotne ujemne powiązania zachodzące pomiędzy skalą Punktacja konfliktów razem a optymizmem $(-0,51)$. Dane te pozwalają przyjąć, że osoby z grupy porównawczej, rzadziej ujawniające konflikty w zakresie odbioru własnego Ja i niestabilność emocjonalną, są optymistycznie nastawione do życia. 
Następna skala samooceny, a mianowicie Akceptacja, koreluje istotnie, również umiarkowanie, ale dodatnio, $\mathrm{z}$ optymizmem $(0,43)$. Zawartość treściowa analizowanej skali sugeruje, że wyższy poziom samoakceptacji i samozadowolenia badanych pełnosprawnych współwystępuje z oczekiwaniem generalnie pozytywnych wydarzeń.

Korelację podobną do wyżej opisanych zauważa się w przypadku skali Ogólna punktacja pozytywna i optymizmu $(0,41)$. Na podstawie opisanych wartości należy sądzić, że osoby widzące, postrzegające siebie jako wartościowe, lubiące siebie, ufające sobie, mają optymistyczną perspektywę przyszłych wydarzeń życiowych.

Przeprowadzona analiza korelacyjna wskazuje na niskie, ale istotne powiązania zachodzące pomiędzy skalą Tożsamość a optymizmem $(0,37)$. Jest to zależność dodatnia. Uzyskany współczynnik informuje, że wyższe poczucie własnej tożsamości badanych z grupy porównawczej, ich silniejsza identyfikacja $\mathrm{z}$ własnym Ja i stawianie sobie wyższych wymagań współwystępują z optymistycznym nastawieniem do życia.

Wyniki uzyskane w skali Samokrytycyzm są nisko ujemnie powiązane z optymizmem (-0,34). Jest to zależność istotna statystycznie. Odwołując się do uzyskanych danych, można przyjąć, że osoby pełnosprawne ujawniające niższy samokrytycyzm i skłonne do ukazywania siebie w lepszym świetle, cechują się oczekiwaniem generalnie pozytywnych wydarzeń.

Ostatni spośród analizowanych związków zależnościowych ma wartość zbliżoną do poziomu istotności statystycznej, a odnosi się do skali Ja fizyczne, nisko, ale dodatnio korelującej z optymizmem (o,30). Zawartość treściowa analizowanej skali samooceny sugeruje, że osoby widzące, przypisujące większą wartość swojemu ciału, zdrowiu, sprawności fizycznej i wyglądowi, mają optymistyczną perspektywę przyszłych wydarzeń życiowych.

\section{Dyskusja}

Uzyskane dane wskazują, że osoby z niepełnosprawnością wzrokową i pełnosprawne nie różnią się na poziomie ufności pod względem optymizmu. Można jedynie powiedzieć o nieco niższym poziomie optymizmu badanych słabowidzących w porównaniu $z$ badanymi widzącymi. Są to jednak pewne tendencje zauważone na podstawie wartości średnich arytmetycznych. Nie mając statystycznych podstaw do orzekania o znaczących różnicach pomiędzy grupami, należy raczej skłonić się ku stwierdzeniu, że osoby z niepełnosprawnością wzrokową i osoby pełnosprawne cechują się podobną perspektywą przyszłych wydarzeń życiowych. Otrzymany wynik wskazuje zatem na duże możliwości osób z grupy podstawowej. Nabiera on szczególnego znaczenia w kontekście opisywanej w literaturze roli optymizmu w rehabilitacji niepełnosprawnych wzrokowo (Ben-Zur, Debi 2005).

Badania pokazały, że w zakresie samooceny odnotowano pomiędzy grupami cztery różnice istotne statystycznie. Okazało się, że osoby słabowidzące znacznie 
rzadziej przypisują sobie cechy dodatnie w postępowaniu moralno-etycznym i rzadziej pozytywnie oceniają swoją osobowość w odrębności od swojego ciała i stosunku do innych. Charakteryzuje je istotnie mniej pozytywny obraz siebie jako członków rodziny oraz słabsze poczucie adekwatności własnej wartości w interakcjach społecznych. Uzyskane wyniki są częściowo zgodne z doniesieniami Maríi D. López-Justicii i Inmaculady Nieto-Córdoby (2006), które wskazały na występowanie istotnych różnic pomiędzy osobami słabowidzącymi i widzącymi w zakresie Ja rodzinnego. Korzystniejsze wyniki były udziałem badanych pełnosprawnych. Autorki zwróciły uwagę na potrzebę określenia rzeczywistej sytuacji życiowej słabowidzących, a zwłaszcza jej percepcji przez te osoby, by w ten sposób zapobiec niepożądanym zjawiskom, tj. poczuciu mniejszej przydatności czy bycia ciężarem, mogącym mieć negatywne konsekwencje dla funkcjonowania osoby z niepełnosprawnością. Jest to tym bardziej zasadne, że w niniejszych badaniach też pojawiły się rozbieżności w skalach: Ja moralno-etyczne, Ja osobiste, Ja społeczne. W zakresie pozostałych wymiarów, nieróżniących się na poziomie ufności, stwierdzono, że badani z niepełnosprawnością wzrokową, w porównaniu z badanymi pełnosprawnymi, mają skłonność do ukazywania siebie w lepszym świetle, definiują własne Ja w sposób mniej harmonijny i posiadają mniejszy potencjał do charakteryzowania siebie poprzez koncentrację na sobie oraz obiektywnej oceny siebie. Nie zaprzeczają nadmiernie swoim cechom negatywnym w porównaniu z tym, jak potwierdzają swoje cechy pozytywne, postrzegają siebie jako osoby mniej wartościowe i cechują się niższym poczuciem tożsamości. Osoby słabowidzące stawiają sobie niższe wymagania, mniej pozytywnie oceniają swoje zachowania i zwracają mniejszą uwagę na swoje ciało. Ponadto odznaczają się większą tendencją do braku jedności pomiędzy poszczególnymi sferami własnego Ja, ujawniają większe zdecydowanie w tym, co robią, i mniejszą defensywność w zakresie percepcji i prezentowania obrazu siebie.

Wyniki analizy korelacyjnej wskazują na istotne związki zależnościowe zachodzące między samooceną a optymizmem badanych osób z niepełnosprawnością wzrokową i osób pełnosprawnych, chociaż konfiguracja zachodzących powiązań jest nieco odmienna. Na podstawie uzyskanych danych należy sądzić, że wyższa samoocena współwystępuje z wyższym poziomem optymizmu. W grupie podstawowej zauważono, że optymistyczne nastawienie do życia koreluje z pozytywnym obrazem siebie jako członka rodziny, wyższym poziomem samoakceptacji i samozadowolenia, postrzeganiem siebie jako osoby wartościowej. Optymizm wiąże się także z wyższą oceną swojego zachowania i osobowości w odrębności od swojego ciała i stosunku do innych. Natomiast w grupie porównawczej zaobserwowano, że oczekiwanie generalnie pozytywnych wydarzeń współwystępuje z mniejszą skłonnością do konfliktu zaprzeczenia, rzadszym ujawnianiem konfliktów w zakresie odbioru własnego Ja, mniejszą niestabilnością emocjonalną i niższym samokrytycyzmem. Poza tym koreluje z wyższym poziomem samoakceptacji i samozadowolenia, z postrzeganiem siebie jako osoby wartościowej, silniejszą 
identyfikacją z własnym Ja i stawianiem sobie wyższych wymagań. W świetle uzyskanych współczynników zasadne jest stwierdzenie, że samoocena ma znaczenie dla kształtowania się optymizmu osób słabowidzących i widzących, a ustalony charakter korelacji jest zbieżny z oczekiwanym, co tym samym potwierdza założenie hipotetyczne i pozytywnie weryfikuje doniesienia teoretyczne i empiryczne zawarte w literaturze przedmiotu (El-Anzi 2005; Lemola 2013; Łaguna i in. 2007; Zeigler-Hill, Terry 2007).

Niniejsze badania wpisują się w nurt orientacji pozytywnej, zyskującej coraz więcej zwolenników.

\section{Wnioski}

1. Optymizm nie różnicuje na poziomie ufności badanych słabowidzących i widzących. Wprawdzie występują pewne różnice na poziomie średnich arytmetycznych na korzyść grupy porównawczej, ale należy raczej wnioskować, że osoby z obu grup cechują się podobną perspektywą przyszłych wydarzeń życiowych.

2. Występują pewne różnice w zakresie samooceny badanych $\mathrm{z}$ niepełnosprawnością wzrokową i pełnosprawnych. W czterech skalach TSCS rozbieżności pomiędzy grupami okazały się istotne statystycznie. Ujawniono, że osoby słabowidzące istotnie rzadziej przypisują sobie cechy dodatnie w postępowaniu moralno-etycznym i pozytywnie oceniają swoją osobowość w odrębności od swojego ciała i stosunku do innych. Cechuje je znacznie mniej pozytywny obraz siebie jako członków rodziny oraz słabsze poczucie adekwatności własnej wartości w interakcjach społecznych.

3. Samoocena ma znaczenie dla kształtowania się optymizmu osób z niepełnosprawnością wzrokową i osób pełnosprawnych. Ustalony charakter korelacji jest zbieżny z oczekiwanym, chociaż konfiguracja zachodzących powiązań jest nieco odmienna. Wysunięte założenie hipotetyczne zostało potwierdzone.

\section{Bibliografia}

Baker S.R. (2007). Dispositional optimism and health status, symptoms and behaviours: assessing idiothetic relationships using a prospective daily diary approach. „Psychology and Health”, 22 (4), s. 431-455.

Ben-Zur H., Debi Z. (2005). Optimism, social comparisons and coping with vision loss in Israel. „Journal of Visual Impairments and Blindness”, 99 (3), s. 151-164.

Ben-Zur H., Rappaport B., Amar R., Uretzky G. (2000). Coping strategies, lifestyle changes and pessimism after open-heart surgery. „Health and Social Work”, 25 (3), s. 201-209.

Carver C.S, Scheier M.F. (2002). The hopeful optimist. „Psychological Inquiry”, 13 (4), s. $288-290$. 
Czapiński J. (2005). Optymiści i ryzykanci. Polskie paradoksy. W: Drogosz M. (red). Jak Polacy przegrywaja, jak Polacy wygrywają? Gdańsk: GWP.

Czapiński J. (2012). Osobowość szczęśliwego człowieka. W: Czapiński J. (red). Psychologia pozytywna. Nauka o szczęściu, zdrowiu, sile i cnotach człowieka. Warszawa: PWN.

El-Anzi F.O. (2005). Academic achievement and its relationship with anxiety, self-esteem, optimism and pessimism in Kuwaiti students. "Social Behavior and Personality: An International Journal”, 33 (1), s. 95-103.

Fila-Jankowska A. (2009). Samoocena autentyczna: co ukrywamy sami przed soba. Warszawa: Wydawnictwo SWPS.

Huflejt-Łukasik M. (2010). Ja i procesy samoregulacji: różnice między zdrowiem a zaburzeniami psychicznymi. Warszawa: Wydawnictwo Scholar.

Isen A.M. (2012). Rola neuropsychologii w zrozumieniu korzystnego wplywu afektu pozytywnego na zachowania społeczne i procesy poznawcze. W: Czapiński J. (red). Psychologia pozytywna. Nauka o szczęściu, zdrowiu, sile i cnotach człowieka. Warszawa: PWN.

Juczyński Z. (2001). Narzędzia pomiaru w psychologii i promocji zdrowia. Warszawa: PTP.

Karademas E.C. (2006). Self-efficacy, social support and well-being: the mediating role of optimism. „Personality and Individual Differences”, 40 (6), s. 1281-129o.

Kirenko J. (2002). Wsparcie społeczne osób z niepełnosprawnością. Ryki: Wydawnictwo WSUPiZ.

Kirenko J., Sarzyńska E. (2010). Bezrobocie, niepełnosprawność, potrzeby. Lublin: Wydawnictwo UMCS.

Kofta M., Doliński D. (200o). Poznawcze podejście do osobowości. W: Strelau J. (red). Psychologia. Podręcznik akademicki. T. 2. Gdańsk: GWP.

Lemola S., Räikkönen K., Gomez V., Allemand M. (2013). Optimism and self-esteem are related to sleep. Results from a large community-based sample. „International Journal of Behavioral Medicine", 20 (4), s. 567-571.

Lindenfield G. (1995). Poczucie własnej wartości. Łódź: Wydawnictwo Ravi.

López-Justicia M.D., Nieto-Córdoba I. (2006). The self-concept of Spanish young adults with retinitis pigmentosa. „Journal of Visual Impairments and Blindness”, 100 (6), s. 366-370.

Łaguna M., Lachowicz-Tabaczek K., Dzwonkowska I. (2007). Skala samooceny Morrisa Rosenberga - polska adaptacja metody. „Psychologia Społeczna”, nr 2, s. $164-176$.

Łatka J., Majda A., Pyrz B. (2013). Dyspozycyjny optymizm a zachowania zdrowotne pacjentów z chorobą nadciśnieniową. „Problemy Pielęgniarstwa”, 21 (1), s. 21-28.

Łobocki M. (2007). Wprowadzenie do metodologii badań pedagogicznych. Kraków: Oficyna Wydawnicza Impuls.

Martinez R., Sewell K.W. (1996). Self-concept of adults with visual impairments. "Journal of Rehabilitation”, 62 (2), s. 55-58. 
Moore L.W., Miller M. (2003). Older men's experiences of living with sever visual impairment. "Journal of Advanced Nursing”, 43 (1), s. 10-18.

Oettingen G., Mayer D. (2002). The motivating function of thinking about the future: Expectations versus fantasies. "Journal of Personality and Social Psychology", 83 (5), s. 1198-1221.

Oleś P. (2005). Wprowadzenie do psychologii osobowości. Warszawa: Wydawnictwo Scholar.

Poprawa R. (2001). Zasoby osobiste w radzeniu sobie ze stresem. W: Dolińska-Zygmunt G. (red). Podstawy psychologii zdrowia. Wrocław: UW.

Scheier M.F., Carver C.S. (1992). Effects of optimism on psychological and physical well-being: theoretical overview and empirical update. „Cognitive Therapy and Research", 16 (2), s. 201-228.

Scheier M.F., Carver C.S., Bridges M.W. (1994). Distinguishing optimism from neuroticism (and trait anxiety, self-mastery, and self-esteem): an reevaluation of the Life Orientation Test. "Journal of Personality and Social Psychology", 67, s. $1063-1078$.

Schwarzer R. (1994). Optimism, vulnerability, and self-beliefs as health-related cognitions: a systematic review. „Psychology and Health”, 9 (3), s. 1161-180.

Segerstrom S.C. (2007). Optimism and resources: effects on each other and on health over 10 years. „Journal of Research in Personality”, 41 (4), s. 772-786.

Seligman M.E. (2002). Optymizmu można się nauczyć. Jak zmieniać swoje myślenie i swoje życie. Poznań: Wydawnictwo Media Rodzina.

Seligman M.E. (2005). Prawdziwe szczęście. Psychologia pozytywna a urzeczywistnianie naszych możliwości trwałego spełniania. Poznań: Wydawnictwo Media Rodzina.

Sękowski T. (2001). Psychologiczne aspekty rehabilitacji zawodowej osób niewidomych zatrudnionych $w$ warunkach pełnej i częściowej integracji. Lublin: Wydawnictwo UMCS.

Shelby R.A., Crespin T.R., Wells-Di Gregorio S.M., Lamdan R.M., Siegel J.E., Taylor K.L. (2008). Optimism, social support, and adjustment in African American women with breast cancer. "Journal of Behavioral Medicine”, 31 (5), s. 433-444.

Stach R. (2006). Optymizm. Badania nad optymizmem jako mechanizmem adaptacyjnym. Kraków: Wydawnictwo UJ.

Tomaszewski T. (1995). Psychologia ogólna. Warszawa: PWN.

Trzebiński J., Zięba M. (2003). Nadzieja, strata i rozwój. „Psychologia Jakości Życia", nr 2, s. 5-33.

Wallston K.A. (1994). Cautious optimism versus cockeyed optimism. „Psychology and Health", 9 (3), s. 201-303.

Wojciszke B. (2008). Człowiek wśród ludzi. Zarys psychologii społecznej. T. 8. Warszawa: Wydawnictwo Scholar.

Zeigler-Hill V., Terry C. (2007). Perfectionism and explicit self-esteem: the moderating role of implicit self-esteem. „Self and Identity”, 6 (2-3), s. 137-153. 


\title{
THE ROLE OF SELF-ESTEEM IN SHAPING OPTIMISM IN INDIVIDUALS WITH LOW VISION
}

\begin{abstract}
Developing a sense of one's own self has a great impact on regulating human behavior, giving, among others, a foundation to set life goals, and taking a positive perspective on future life events. Optimism also influences many life spheres, such as social functioning, mental and physical health. Self-esteem and optimism in how individuals function, and the correlations between these variables are especially important for individuals with disability. The following research was to diagnose the role of self-esteem in shaping optimism in individuals with low vision. Research was conducted with respondents aged 20-30 - there were 40 respondents with low vision and 40 able-bodied respondents. Research findings that self-esteem is important in developing optimism in individuals with low vision and able-bodied respondents. The nature of correlation obtained in the research was convergent with the expected, though the configuration of correlations in both groups is slightly different. The hypothesis was corroborated.
\end{abstract}

Key words: self-esteem, optimism, individuals with low vision

Beata Szabała - doktor, adiunkt w Zakładzie Socjopedagogiki Specjalnej UMCS. Autorka 4 monografii, w tym jednej autorskiej i trzech współautorskich, oraz współredaktorka dwóch prac. Wybrane publikacje: Rodzina dziecka z cukrzyca (2009); Stereotypy niepetnosprawności. Między wykluczeniem a integracja (2010; współautorzy: M. Chodkowska, S. Byra, Z. Kazanowski, M. Parchomiuk, D. Osik-Chudowolska); Młodzież wobec moralności w zawodach kreujących sferę publiczna (2010; współautorzy: M. Chodkowska, S. Byra, Z. Kazanowski, M. Parchomiuk); Dystans społeczny w pedagogice specjalnej. T. 1. Przyczyny - konsekwencje - przeciwdziałanie (2012; współredaktor M. Parchomiuk); Osoby $z$ upośledzeniem umysłowym w stereotypowym postrzeganiu społecznym (2012; współautor M. Chodkowska); Social distance towards individuals with disability as a problem in special pedagogy. Vol. 2. Socio-educational contexts (2012; współredaktor M. Parchomiuk). Zainteresowania badawcze: zasoby osobiste a niepełnosprawność intelektualna i wzrokowa; psychospołeczne funkcjonowanie rodziców dzieci niepełnosprawnych. Adres do korespondencji: Zakład Socjopedagogiki Specjalnej UMCS, ul. Narutowicza 12, 20-004 Lublin. Adres e-mail: betszb@wp.pl. 